\title{
Does the effect of aquatic plant types on invertebrate assemblages change across seasons in a subtropical wetland?
}

\author{
Luciana I. Gallardo ${ }^{1, *}$, Romina P. Carnevali ${ }^{1,3}$, Eduardo A. Porcel ${ }^{2}$ and Alicia S. G. Poi ${ }^{1,3}$ \\ ${ }^{1}$ Centro de Ecología Aplicada del Litoral - CECOAL (CCT Nordeste - CONICET-UNNE), Ruta 5 km 2.5, \\ (3400) Corrientes, Argentina. \\ ${ }^{2}$ Cátedra de Bioestadística, Facultad de Ciencias Exactas y Naturales y Agrimensura-FACENA, Universidad \\ Nacional del Nordeste-UNNE, Av. Libertad 5470, (3400) Corrientes, Argentina. \\ ${ }^{3}$ Cátedra de Limnología, Facultad de Ciencias Exactas y Naturales y Agrimensura-FACENA, Universidad \\ Nacional del Nordeste-UNNE, Av. Libertad 5470, (3400) Corrientes, Argentina.
}

* Corresponding author: lucianagallardo@hotmail.com

Received: $16 / 05 / 16$

Accepted: 20/01/17

\begin{abstract}
Does the effect of aquatic plant types on invertebrate assemblages change across seasons in a subtropical wetland?

Habitat complexity is one of the fundamental factors determining the distribution of invertebrate assemblages due to the different architectures and growth forms of aquatic plants, which affect their density, species richness, biomass, and trophic structure. In this paper, we compared the density and richness of macroinvertebrates present in two species of aquatic plants with different architectures (Salvinia biloba and Egeria najas) across seasons. Samples of aquatic plants and associated invertebrates were collected seasonally in a wetland located in Corrientes (Argentina) with a net area of $962 \mathrm{~cm}^{2}$. To characterize the different habitat types, we selected 12 traits of aquatic plants, including fractal complexity. A total of 15225 invertebrates from 13 major groups were recorded from both habitat types (41 families and 24 genera in S. biloba and 24 families and 22 genera in E. najas). Significant differences in the total density (number of invertebrates per $1000 \mathrm{~g}$ plant dry weight) and taxa richness at family level were found between habitat types. Non-metric multidimensional scaling reflected differences in the seasonal patterns of 16 macroinvertebrate genera selected between both habitat types. A Similarity Analysis showed statistically significant differences between the habitat types and seasons. Structurally more complex habitat (S. biloba) supported a greater number of taxa and the highest number of individuals per plant dry weight. The differences in the density and richness of the invertebrate assemblages between S. biloba and E. najas were maintained throughout the seasons. The habitat structuring of aquatic macrophytes is a key factor in macroinvertebrate assemblages, and it is important to keep in mind when comparing wetlands with different aquatic vegetation.
\end{abstract}

Key words: Habitat types, habitat complexity, aquatic plants, Salvinia biloba, Egeria najas, invertebrates, subtropical wetland, temporal variation.

\section{RESUMEN}

¿El efecto de los tipos de plantas acuáticas sobre los ensambles de invertebrados cambia en las distintas estaciones en un humedal subtropical?

La complejidad del hábitat es uno de los factores fundamentales que determinan la distribución de los ensambles de invertebrados debido a que las diferentes arquitecturas y formas de crecimiento de las plantas acuáticas afectan su abundancia, riqueza de especies, biomasa y estructura trófica. En este trabajo comparamos la abundancia y riqueza de los macroinvertebrados presentes en dos especies de plantas acuáticas con diferente arquitectura (Salvinia biloba $y$ Egeria najas) en distintas estaciones del año. Las muestras de plantas acuáticas y los invertebrados vinculados fueron recolectadas estacionalmente en un humedal localizado en la provincia de Corrientes (Argentina) con una red de $962 \mathrm{~cm}^{2}$ de área. Para caracterizar los diferentes tipos de hábitats, se seleccionaron 12 rasgos de las plantas acuáticas, incluyendo la dimensión fractal. Un total de 15225 invertebrados de 13 grupos mayores fueron registrados en ambos tipos de hábitats (41 familias y 24 géneros en S. biloba y 24 familias y 22 géneros en $\mathrm{E}$. najas). Se hallaron diferencias estadísticamente significativas en la abundancia total (número de invertebrados por $1000 \mathrm{~g}$ de peso seco de vegetación) y la riqueza de taxones a nivel de 
familias entre tipos de hábitats. El análisis de Escalamiento Multidimensional No Métrico (NMDS) mostró diferencias en los patrones estacionales de 16 géneros de macroinvertebrados seleccionados entre ambos tipos de hábitat. El análisis de Similaridad mostró diferencias estadísticamente significativas entre tipos de hábitat y estaciones. El hábitat que presentó mayor complejidad estructural (S. biloba) albergó mayor número de taxones y de individuos por peso seco de vegetación. Las diferencias en la abundancia y riqueza de las comunidades de invertebrados entre S. biloba y E. najas fueron mantenidas en las distintas estaciones. La estructuración del hábitat por parte de las macrófitas acuáticas es un factor clave para los ensambles de macroinvertebrados y necesita ser tenida en cuenta cuando se realizan comparaciones entre humedales con diferente vegetación acuática.

Palabras clave: Tipos de hábitat, complejidad del hábitat, plantas acuáticas, Salvinia biloba, Egeria najas, invertebrados, humedal subtropical, variación temporal.

\section{INTRODUCTION}

Aquatic plants provide required conditions for feeding, breeding, spawning and rearing of animals as well as shelter against predators for invertebrates and small sized fish (Lachavanne \& Juge, 1997; Esteves, 2011). The macrophyte growth forms influence dominant fish in subtropical shallow lakes and have a cascading effect on other communities such as plankton (Meerhoff et al., 2003).

The composition and trophic structure of macroinvertebrates is often affected by plant community types that occur in a wetland (Batzer \& Wissinger, 1996; Kratzer \& Batzer, 2007; Fontanarrosa et al., 2013). Habitat structuring is one of the fundamental factors determining the distribution of organisms at all spatial scales, and vegetation is of primary importance in shaping the structural environment for invertebrates in a variety of systems (McAbendroth et al., 2005). The abundance of phytophilous invertebrates was found to be related to plant biomass, macrophyte bed characteristics, and sampling date during an intensive survey of submerged aquatic plants in temperate lakes (Cyr \& Downing, 1988). The invertebrate species richness on free and rooted floating plants in floodplain wetlands connected to the Paraná River (Poi de Neiff \& Neiff, 2006; Thomaz et al., 2008; Fontanarrosa et al., 2013) was affected by the specific composition of the macrophytes and was related to plant biomass (Poi de Neiff \& Neiff, 2006), the percentage of plant cover, and the plant dry weight (Fontanarrosa et al., 2013).
Under the same limnological conditions, growth forms and the macrophyte type had effects on macroinvertebrate abundance (Walker $e t$ $a l ., 2013)$ and biomass (Tessier et al., 2004). The size, leaf area, morphology index, and rugosity of leaves are some of the morphological traits that indicate the complexity of the plant architecture (Vieira et al., 2007; Warfe et al., 2008; Monção et al., 2012; Walker et al., 2013). The fractal geometry theory emerged as a tool to measure habitat complexity and has been applied at large spatial scales in different environments (Dibble \& Thomaz, 2009). The fractal index was related to invertebrate abundance (Ferreiro et al., 2011), species richness (Thomaz et al., 2008), biomass-body size scaling, and overall invertebrate biomass (McAbendroth et al., 2005).

In subtropical wetlands fed by rain, the lack of strong temporal variation in macroinvertebrate assemblages is frequent (Kratzer \& Batzer, 2007), but the seasonal pattern is highly variable in seasonally flooded wetlands (Miller et al., 2008).

In this paper, we compared the abundance and richness of macroinvertebrates present in two species of aquatic plants with different morphology traits (Salvinia biloba and Egeria najas) inhabiting a subtropical lake across seasons. We tested the following hypotheses: $a$ ) free floating plants (S. biloba) provide a more complex habitat because of their submerged and aerial fronds, such as those of E. najas, which grows completely submerged, and $b$ ) the effect of habitat structuring on invertebrates (spatial pattern) is more important than the seasonal pattern because of the subtropical climate. 


\section{MATERIALS AND METHODS}

\section{Study Area}

The study was carried out in a small $\left(625390 \mathrm{~m}^{2}\right)$, shallow (mean depth: $1.23 \mathrm{~m}$ ) lake, located in Northeast Argentina (Sánches Lake, 28 $10^{\prime} 07^{\prime \prime}$ $\mathrm{S} ; 58^{\circ} 38^{\prime} 37^{\prime \prime} \mathrm{W}$ ). This chosen lake is representative of sub-rounded lakes fed by rain located in the great wetlands of Corrientes province (Poi \& Galassi, 2013), which encompasses $35660 \mathrm{~km}^{2}$. The dominant plant species were Salvinia biloba Raddi, 1825 and Egeria najas Planch, 1849, which are indicative of two different habitat types characterized by their structural complexity. Salvinia spp. is an endemic genus of neotropical-river flood plains system that occurs in the disconnected lakes and is invasive in warm waters of different continents (Monção et al., 2012). E. najas is native to the Paraná system and typically occurs in high transparent ponds with remote influence on the Paraná river in Argentina (Neiff, 1986). This species forms large masses of vegetation and causes serious problems in reservoirs of tropical and sub-tropical regions (Bini et al., 1999).

\section{Sampling Methods}

Four samples of each aquatic plant (S. biloba and E. najas) and associated invertebrates were collected during spring (September 2010), summer (December 2010), autumn (April 2011), and winter (July 2011), using a net area of $962 \mathrm{~cm}^{2}$ and a $500 \mu \mathrm{m}$ mesh size (Poi de Neiff \& Carignan, 1997). The plants and macroinvertebrates were removed from the net, transferred to plastic bags, and preserved with $95 \%$ ethanol. On each date, we measured physical and chemical variables of the water such as temperature, dissolved oxygen, $\mathrm{pH}$, salinity, conductivity, and transparency using specific measuring instruments.

In the laboratory, the aquatic plants were thoroughly washed to detach the invertebrates, and the suspensions obtained were filtered through $1 \mathrm{~mm}$ and $500 \mu \mathrm{m}$ sieves. The invertebrates were sorted and re-preserved in $70 \%$ ethanol, and the plants were dried to constant weight at $105^{\circ} \mathrm{C}$ for 48 hours and weighed. The invertebrates were counted and identified to the lowest possible taxonomic level using keys from Angrisano, 1992; Lopretto \& Tell, 1995; Trivinho-Strixino \& Strixino, 1995; Thorp \& Covich, 2001; Michat et al., 2008; Domínguez \& Fernández, 2009; Ramírez, 2010; Libonatti et al., 2011. In tropical and subtropical aquatic habitats, the invertebrate diversity is poorly known and taxonomic identification becomes difficult (specifically to the species or genus level) because descriptions of some taxa are incomplete and specific taxonomic keys are scarce. Additionally, the dominance of immature forms (larvae, nymphs and pupae) of many insects with adult aerial life (Diptera, Odonata, Ephemeroptera, Lepidoptera and Trichoptera) makes identification more difficult. Therefore, the use of family or even morphospecies richness has been suggested by Jacobsen et al. (2008). The density of invertebrates was expressed as individuals per $1000 \mathrm{~g}$ plant dry weight, which allows for the comparison of both life forms. This reference unit is neither affected by the changes in the plant cover of free floating plants, nor by changes in E. najas volume. In S. biloba, the number of individuals per $\mathrm{m}^{2}$ was also calculated.

To characterize the different habitat types, we selected 12 traits of aquatic plants according to the criteria proposed by Willby et al. (2000) and Monção et al. (2012). To calculate fractal dimensions of S. biloba and E. najas, four representative portions of each aquatic plant species were photographed with a Canon Rebel T3/EOS 1100D (12.2 megapixels, zoom lens EF-S 18-55 $\mathrm{mm}$ ) digital camera, capturing an area of (100.47 $\times 150.71 \mathrm{~cm}^{2}$ ). A minimum of four pictures of each portion was taken. The programme Adobe Photoshop CS5 Extended 12.0 was used to transferred selected TIFF images to greyscale and bits map to produce a black and white image and then modified to adjust background shades to improve resolution of plants features (Dibble \& Thomaz, 2009). The fractal dimensions (D) of both area and perimeter were calculated using the box counting method (Sugihara \& May, 1990) with the program ImageJ $1.49 \mathrm{v}$ (Rasband, 2015). A series of grid sizes of 2, 4, 6, 8, 12, 16, 32, 64, 
Table 1. Traits of aquatic plants that characterize the different habitat types. Rasgos de las plantas acuáticas que caracterizan los diferentes tipos de hábitats.

\begin{tabular}{ccc}
\hline Traits & Salvinia biloba & Egeria najas \\
\hline Size & $\leq 15 \mathrm{~cm}$ & $\leq 200 \mathrm{~cm}$ \\
Growth form & Free-floating, surface & Anchored, submerged and/or floating leaves \\
Eilobed, opposite, with hairy & Entire, curl down and serrated, \\
Frond/leaf features & emergencies on upper surface & typically in whorls of 5 at each node \\
Rhizome/stalk & Creeping and hairy rhizome & Stalk of 0.5 to $1.5 \mathrm{~cm} \mathrm{diameter}^{2}$ \\
Frond/leaf area & Medium $\left(1-20 \mathrm{~cm}^{2}\right)$ & Small $\left(<1 \mathrm{~cm}^{2}\right)$ \\
Maximum width of the leaf & $2 \pm 0.39 \mathrm{~cm}$ & $0.25 \pm 0.03 \mathrm{~cm}^{2}$ \\
Frond/leaf perimeter & $10 \pm 2.05 \mathrm{~cm}$ & $3.88 \pm 0.42 \mathrm{~cm}$ \\
Plant biomass & $132.43 \pm 26.48 \mathrm{~g} / \mathrm{m}^{2}$ & $290.14 \pm 44.96 \mathrm{~g} / \mathrm{m}^{2}$ \\
Submerged fronds length & $4 \pm 0.76 \mathrm{~cm}$ & - \\
Fractal Dimensions & $1.84 \pm 0.04(\mathrm{area})$ & $1.81 \pm 0.02($ area $)$ \\
Sexual/asexual reproduction & $1.58 \pm 0.05($ perimeter $)$ & $1.44 \pm 0.03(\mathrm{perimeter})$ \\
Perennation & Spores/Rhizomes & Seeds $/$ Stem fragments \\
& Perennial & Perennial
\end{tabular}

128 and 256 pixel widths (Thomaz et al., 2008) were used to estimate fractal dimensions.

\section{Data Analysis}

To compare the abundance and family richness of invertebrate assemblages found in S. biloba and E. najas across seasons, a Kruskal-Wallis test was carried out. To assess annual patterns in in- vertebrate assemblages, the density of 16 dominant genera/species were ordered using a Nonmetric Multidimensional Scaling (NMDS). The results were confirmed by a Similarity Analysis (ANOSIM), Clarke (1993), using the Bray Curtis distance. To examine the spatial and temporal $\beta$ diversity, we used the Complementary Coefficient (Colwell \& Coddington, 1994). The statistical analysis was performed using PAST 2.08

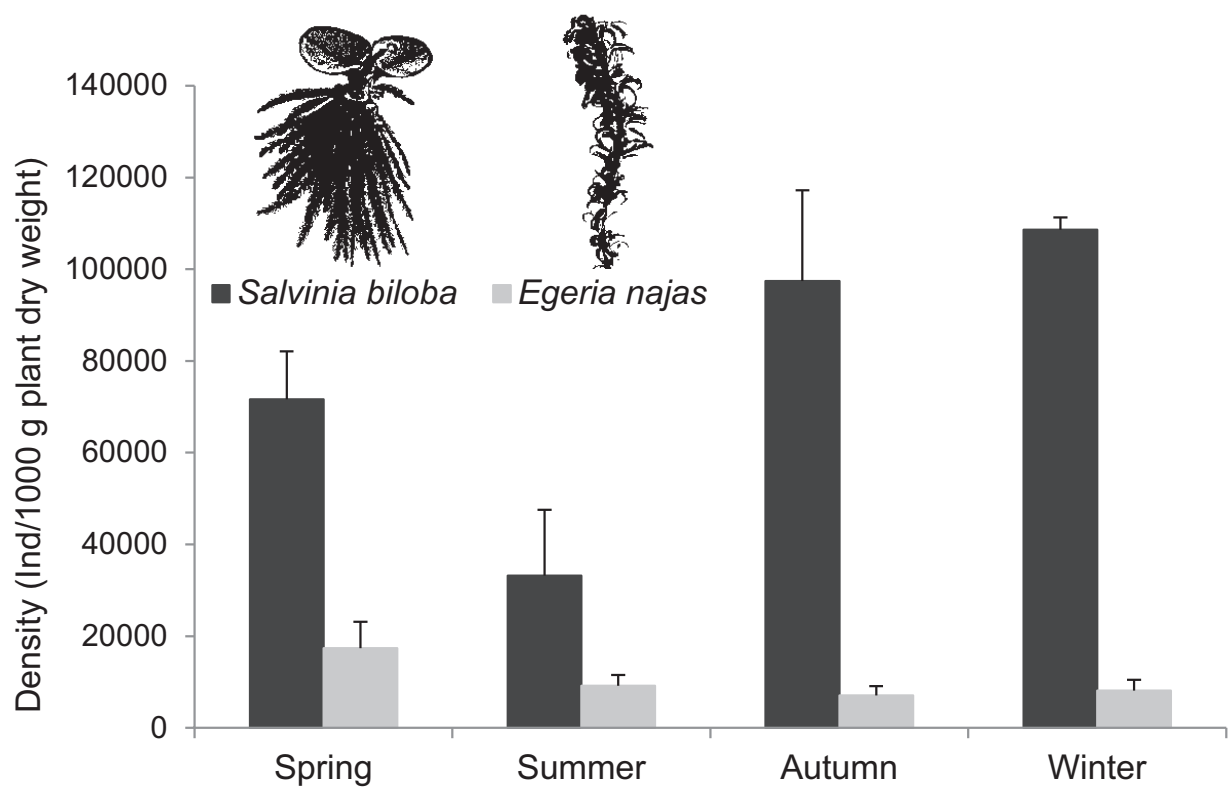

Figure 1. Macroinvertebrates mean density in both habitat types in different seasons. The bars show standard deviations. Abundancia media de macroinvertebrados en ambos tipos de hábitat en diferentes estaciones. Las barras muestran los desvíos estándar. 
Table 2. Relative density (\%) of macroinvertebrate families found in both habitat types in different seasons (Sp: spring, Su: summer, $\mathrm{Au}$ : autumn, Wi: winter). Abundancia relativa (\%) de las familias de macroinvertebrados halladas en ambos tipos de hábitat en diferentes estaciones (Sp: primavera, Su: verano, Au: otoño, Wi: invierno).

\begin{tabular}{|c|c|c|c|c|c|c|c|c|}
\hline \multirow[b]{2}{*}{ Taxa } & \multicolumn{4}{|c|}{ Salvinia biloba } & \multicolumn{4}{|c|}{ Egeria najas } \\
\hline & $\mathrm{Sp}$ & $\mathrm{Su}$ & $\overline{\mathrm{Au}}$ & Wi & $\mathrm{Sp}$ & $\mathrm{Su}$ & $\overline{\mathrm{Au}}$ & $\mathrm{Wi}$ \\
\hline INSECTA & & & & & & & & \\
\hline Lepidoptera & & & 1.28 & & & & & \\
\hline Crambidae & 0.15 & & & 0.04 & & & & \\
\hline Nepticulidae & & & & 0.04 & & & & \\
\hline \multicolumn{9}{|l|}{ Diptera } \\
\hline Chironomidae & 14.98 & 13.45 & 38.47 & 8.11 & 76.55 & 31.45 & 29.41 & 23.53 \\
\hline Ceratopogonidae & 37.84 & 6.72 & 9.37 & 9.21 & 0.09 & 0.16 & 0.26 & \\
\hline Culicidae & 0.78 & 1.38 & 2.93 & & & & & \\
\hline Tabanidae & 0.30 & & 0.05 & 0.51 & & & & \\
\hline Stratiomyidae & & 0.53 & 1.64 & 0.51 & & & & \\
\hline Ephydridae & & 1.01 & & 0.17 & 0.95 & 0.61 & 2.16 & 0.34 \\
\hline \multicolumn{9}{|l|}{ Odonata } \\
\hline Coenagrionidae & 0.56 & 2.05 & 2.37 & 1.99 & 1.33 & 2.26 & 2.46 & 4.96 \\
\hline $\begin{array}{l}\text { Libellulidae } \\
\text { Coleoptera }\end{array}$ & 0.61 & 0.55 & 0.44 & 1.00 & & 0.75 & 0.12 & 0.34 \\
\hline Curculionidae & 0.25 & 0.69 & 0.18 & & 0.56 & 1.30 & 1.23 & 1.98 \\
\hline Hydrophilidae & 1.82 & 12.54 & 8.01 & 10.57 & & & & \\
\hline Dytiscidae & 0.26 & 4.18 & 2.44 & 4.75 & & 1.79 & & \\
\hline Noteridae & 0.70 & 1.64 & 1.74 & 2.57 & 0.32 & & 0.19 & \\
\hline Hydrochidae & & & & 0.13 & & & & \\
\hline Scirtidae & & 1.50 & 4.16 & 1.95 & & & & \\
\hline Chrysomelidae & & & & 0.72 & & & & \\
\hline Scarabeidae & & & & 0.04 & & & & \\
\hline Staphylinidae & 0.18 & 0.30 & 0.06 & 0.04 & & & & \\
\hline Lampyridae & & 0.11 & 0.07 & 0.43 & & & & \\
\hline Pselaphidae & & 0.58 & 0.03 & & & & & \\
\hline \multicolumn{9}{|l|}{ Heteroptera } \\
\hline Lygaeidae & & & 2.29 & 0.08 & & & & \\
\hline Corixidae & & & & & 0.57 & 1.72 & 0.22 & \\
\hline Naucoridae & 0.13 & 0.38 & 0.45 & 0.55 & & 0.45 & 1.06 & \\
\hline Pleidae & 0.32 & 0.64 & 0.03 & 0.51 & 0.80 & 1.92 & 0.12 & \\
\hline Hebridae & 1.18 & 5.68 & 3.95 & & & & & \\
\hline Belostomatidae & 0.06 & 0.11 & 0.36 & 0.21 & & & & \\
\hline Nepidae & 0.02 & & & & & & & \\
\hline Aphididae & & & & 0.50 & & & & \\
\hline \multicolumn{9}{|l|}{ Ephemeroptera } \\
\hline Caenidae & 1.39 & 0.50 & 0.03 & 0.55 & 0.38 & 0.42 & 0.93 & 0.19 \\
\hline Baetidae & 0.04 & 0.07 & 0.09 & & & 0.44 & 0.82 & 0.13 \\
\hline Trichoptera & & & & & & & 0.97 & \\
\hline Hydroptilidae & 0.87 & & & & & & & \\
\hline Polycentropodidae & & & & 0.04 & & & & \\
\hline Leptoceridae & & & & & & & & 0.44 \\
\hline Psychomyiidae & & 0.27 & 0.19 & & & & & 0.46 \\
\hline \multicolumn{9}{|l|}{ Orthoptera } \\
\hline Acrididae & & & 0.25 & & & & & \\
\hline \multicolumn{9}{|l|}{ ARACHNIDA } \\
\hline \multicolumn{9}{|l|}{ Araneae } \\
\hline HIDRACARINA & 0.69 & 4.47 & 4.85 & 1.64 & 0.13 & 2.32 & 2.89 & 16.79 \\
\hline COLLEMBOLA & & & & 0.09 & & & & \\
\hline OSTRACODA & 1.97 & 3.10 & & 0.76 & 2.79 & & 2.30 & 0.76 \\
\hline AMPHIPODA & & & & & & & & \\
\hline Hyalellidae & 6.20 & 14.52 & 0.26 & 34.68 & 3.21 & 11.99 & 0.59 & 10.23 \\
\hline \multicolumn{9}{|l|}{ DECAPODA } \\
\hline Potamonidae & & & & 0.04 & & & & \\
\hline Palaemonidae & & & & & 6.10 & 0.87 & 4.58 & 6.78 \\
\hline CLADOCERA & 1.55 & & & 1.76 & & & & \\
\hline COPEPODA & 4.89 & & & 7.18 & & & & \\
\hline GASTROPODA & & & & & & & & \\
\hline Planorbiidae & 0.79 & 1.40 & 1.72 & 0.59 & & & 0.12 & \\
\hline Ancylidae & 0.42 & 0.66 & 0.03 & & 1.81 & 12.93 & 29.63 & 25.92 \\
\hline Ampullaridae & & & & & 0.15 & 1.41 & & \\
\hline HIRUDINEA & & & & & & & & \\
\hline Glossiphonidae & 0.26 & 0.43 & 0.67 & 1.22 & 0.81 & 0.21 & 0.49 & 0.10 \\
\hline OLIGOCHAETA & & & & & & & & \\
\hline $\begin{array}{l}\text { Naididae } \\
\text { NEMATODA }\end{array}$ & 20.83 & 20.53 & 11.63 & $\begin{array}{l}4.77 \\
1.44\end{array}$ & 3.45 & 27.01 & 19.64 & 6.86 \\
\hline TOTAL ABUNDANCE & 4040 & 1637 & 3243 & 2344 & 1227 & 526 & 937 & 797 \\
\hline
\end{tabular}




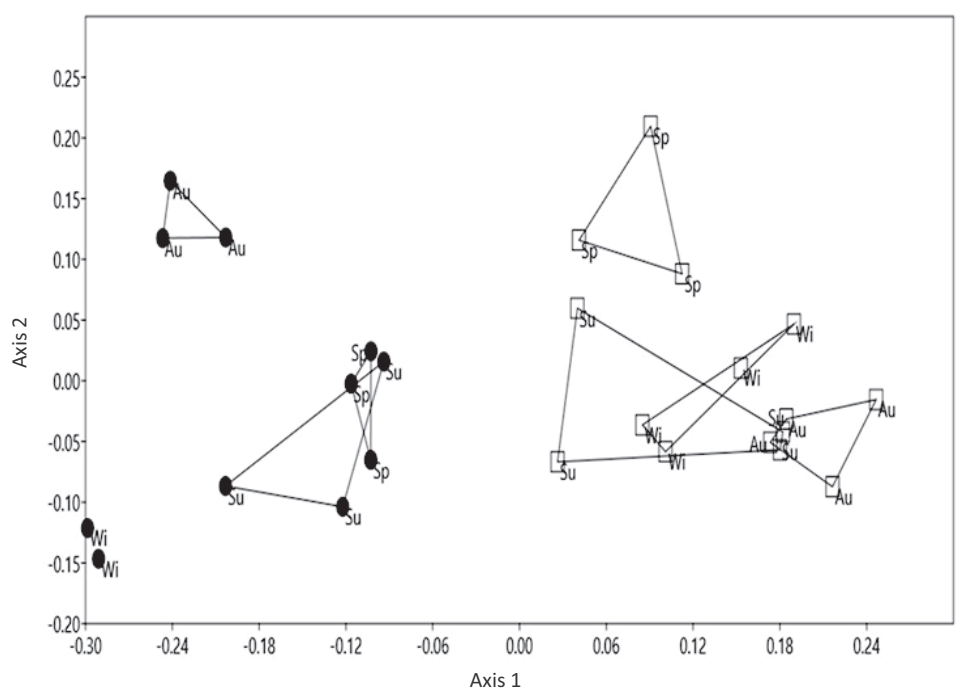

Figure 2. Non-metric multidimensional scaling (NMDS) plot showing macroinvertebrate density between habitat types ( $S$. biloba and E. najas) and between seasons. References: • S. biloba, $\square$ E. najas, Sp: spring, Su: summer, Au: autumn, Wi: Winter. Gráfico de Escalamiento Multidimensional No Métrico (NMDS) mostrando la abundancia de los macroinvertebrados entre tipos de hábitat (S. biloba and E. najas) y entre estaciones. Referencias: • S. biloba, $\square$ E. najas, Sp: primavera, Su: verano, Au: otoño, Wi: invierno.

(Hammer, 2001) and InfoStat (Di Rienzo et al., 2013) software.

\section{RESULTS}

\section{Study area}

During the studied period, the water was transparent and its dissolved oxygen concentration was high (mean $8.02 \pm 0.71 \mathrm{mg} / \mathrm{L})$. The water temperatures were generally high $\left(13.9{ }^{\circ} \mathrm{C}\right.$ in winter and $31{ }^{\circ} \mathrm{C}$ in summer), $\mathrm{pH}$ values were around neutrality (between 6.5 and 7.4), and the electrical conductivity ranged between 57 and $73 \mu \mathrm{S} / \mathrm{cm}$. The phosphorus and total nitrogen content varied between 95 and $105 \mu \mathrm{g} / \mathrm{L}$ and 25 and $38 \mu \mathrm{g} / \mathrm{L}$, respectively.

Salvinia biloba comprised a narrow stripe in all of the littoral area in the study lake, while $E$. najas covered $35 \%$ of the lake area. Both species coexisted under the same limnological conditions in monospecific stands. S. biloba had more complex plant architecture and habitat complexity (aerial and submerged fronds) than E. najas (Table 1). However, the values obtained from fractal dimension estimation of both area and perimeter, were slightly higher. The number of plants per unit surface changed during the sampling period in the free floating mats of S. biloba, mainly due to wind action. The plant biomass per $\mathrm{m}^{2}$ varied across seasons, and its mean value is shown in Table 1.

\section{Abundance and taxa richness of invertebrate assemblages}

A total of 15225 invertebrates from 13 major groups were recorded from both habitat types $(S$. biloba and E. najas). We found 41 families and 24 genera in S. biloba and 24 families and 22 genera in E. najas. There were seasonal variations in the relative abundance and specific arrangement of invertebrate taxa in both habitats (Table 2). In addition, significant differences in taxa richness $(H=5.33 ; p<0.0286)$ were found between habitat types. The most abundant families on S. biloba were Chironomidae, Ceratopogonidae, Hyalellidae and Naididae. The invertebrate density of E. najas was dominated by Chironomidae, Naididae and Ancylidae (Table 2).

When density was expressed as invertebrates/1000 g plant dry weight, the total number was significantly higher $(H=18.33 ; p<0.0001)$ 
in S. biloba than in E. najas (Fig. 1). The maximum density was found in S. biloba during winter (108 605 ind/1000 g plant dry weight), whereas E. najas reached 17374 ind/1000 g plant dry weight in spring. When the density was expressed as invertebrates $/ \mathrm{m}^{2}$, the total mean number on S. biloba varied between $5672( \pm 138.43)$ in summer and $13998( \pm 5747.57)$ in spring.

Non-metric multidimensional scaling (NMDS) reflected differences in the seasonal patterns of the 16 genera selected between both habitat types (S. biloba and E. najas). The first axis of NMDS analysis differentiates invertebrate density between the habitat types, whereas the second axis shows differences between seasons (Fig. 2). The NMDS assemblage ordination had an acceptably low final stress $(12 \%)$. The genera associated with S. biloba and E. najas are grouped on the left and right of the first axis, respectively. In S. biloba, the assemblage was similar in spring and summer and differed in autumn and winter, while in E. najas, the invertebrate assemblage found in spring was different than that found in other seasons. These results were confirmed by

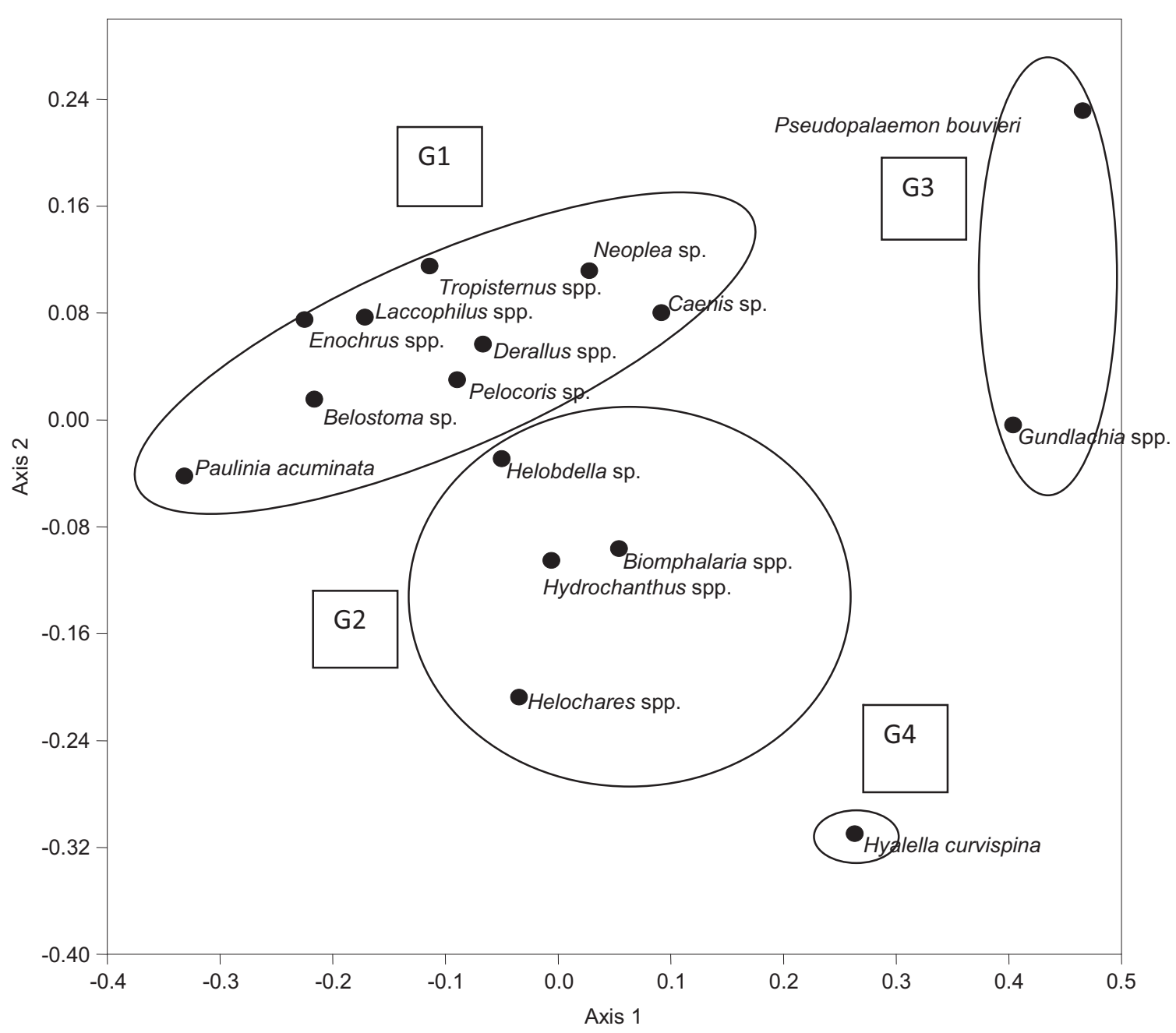

Figure 3. Non-metric multidimensional scaling (NMDS) plot showing macroinvertebrate genera grouping. G1: group 1, G2: group 2, G3: group 3, G4: group 4. Gráfico de Escalamiento Multidimensional No Métrico (NMDS) mostrando el agrupamiento de los géneros de macroinvertebrados. G1: grupo 1, G2: grupo 2, G3: grupo 3, G4: grupo 4. 

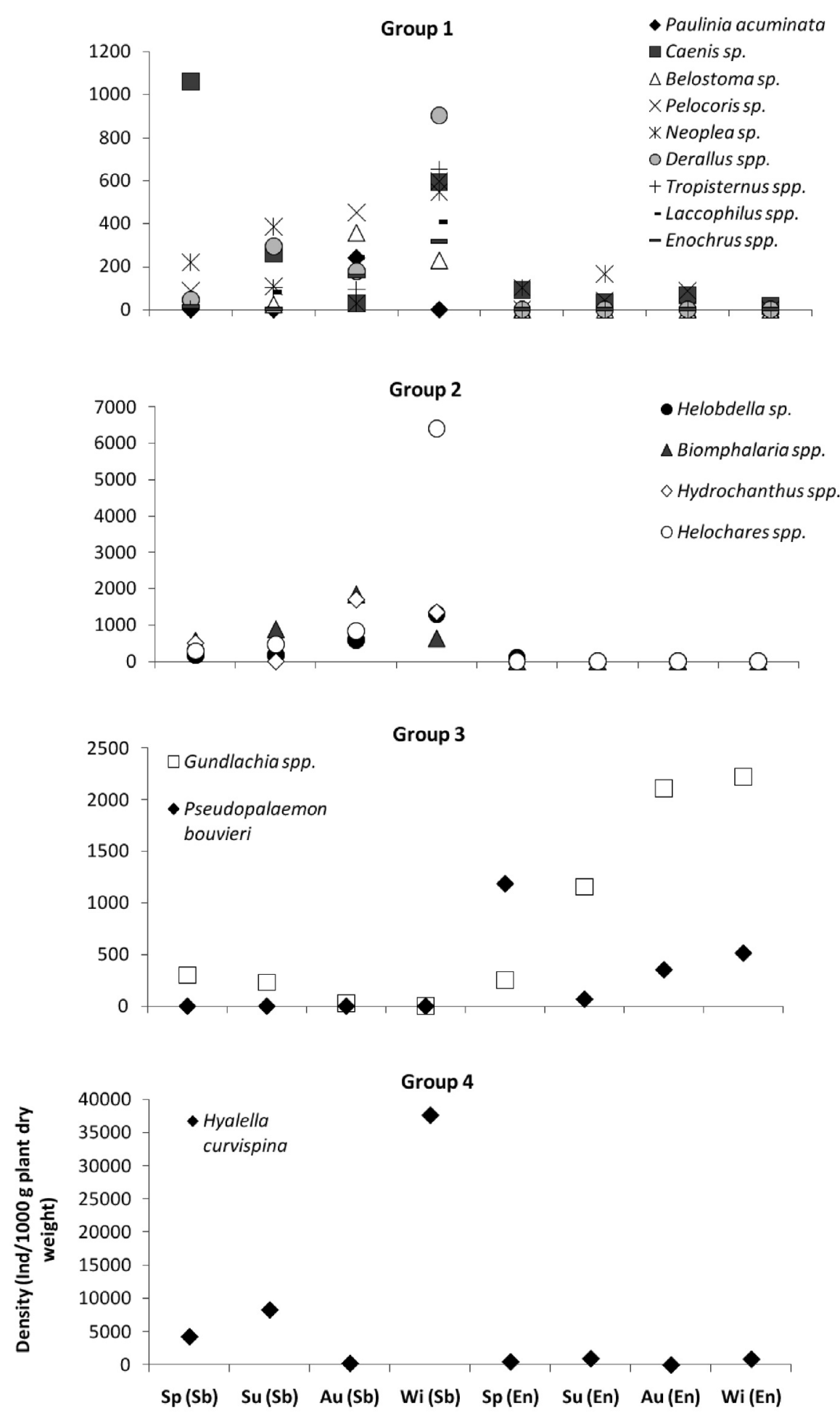

Figure 4. Temporal variation of the mean density of macroinvertebrate species of the 4 groups in both habitat types. Sp: spring, Su: summer, Au: autumn, Wi: winter, (Sb): Salvinia biloba, (En): Egeria najas. Variación temporal de la densidad media de las especies de macroinvertebrados de los 4 grupos en ambos tipos de hábitat. Sp: primavera, Su: verano, Au: otoño, Wi: invierno, (Sb): Salvinia biloba, $(E n)$ : Egeria najas. 
a Similarity Analysis (ANOSIM) that showed statistically significant differences between habitat types $(R=0.94, p=0.0001)$ and seasons $(R=0.55, p=0.0001)$.

In a second NMDS, the R stress value (10\%) was also acceptably low (Fig. 3). The invertebrate genera associated with $S$. biloba are grouped to the left of the first axis and those associated with $E$. najas, to the right. The plot shows the differentiation of 4 groups, with the first one (G1) placed in the upper left quadrant of the plot comprising 9 grouped invertebrate genera with low densities in autumn and winter. Paulinia acuminata, De Geer, 1773, Belostoma sp., Tropisternus spp., Enochrus spp., Derallus spp. and Laccophilus spp. were not found in $E$. najas. These genera peaked at winter except for Belostoma sp. (Fig. 4).

The second group (G2) presented a high mean density in S. biloba (Fig. 4) with genera peaking at winter (Helochares spp.) and autumn (Hydrochanthus spp. and Biomphalaria spp.). The third group (G3) presented two species (Gundlachia sp. and Pseudopalaemon bouvieri, Sollaud, 1911) that were registered with a major mean density in E. najas during winter (Fig. 4). $P$. bouvieri was not registered in S. biloba. The fourth group (G4) presented a unique species (Hyalella curvispina, Shoemaker, 1942) that appeared with major frequency and mean density in S. biloba (Fig. 4) during winter.

The values of Complementary Coefficient across seasons ( $\beta$ temporal diversity) were low for both habitat types (Table 3 ). When we analysed $\beta$ diversity between habitat types ( $\beta$ spatial diversity), the values were higher in the winter (0.733) than those calculated for spring, summer (0.538) and autumn (0.625).

\section{DISCUSSION}

Our results indicate that Salvinia biloba supports a greater number of taxa and the highest number of individual per plant dry weight than Egeria najas. S. biloba is a structurally more complex habitat (aerial and submerged fronds), but the fractal dimensions do not reflected this complex-
Table 3. Complementary Coefficient values for both habitat types, comparing different time periods. Valores del Coeficiente de Complementariedad para ambos tipos de hábitats, comparando diferentes períodos de tiempo.

\begin{tabular}{lcc}
\hline & Salvinia biloba & Egeria najas \\
\hline spring-summer & 0.285 & 0.250 \\
summer-autumn & 0.200 & 0.250 \\
autumn-winter & 0.133 & 0.375 \\
\hline
\end{tabular}

ity. The values of fractal dimensions obtained in this work were similar to those mentioned in the bibliography for the same aquatic plants species (Dibble \& Thomaz, 2009; Matsuda et al., 2015). The differences in the abundance and richness of the invertebrate assemblages between $S$. biloba and $E$. najas were maintained along the seasons. Habitat complexity provided by the different architecture of aquatic plants affects both the number of taxa and density of invertebrates (Thomaz et al., 2008). However, other studies indicate that macrophytes with greater complexity support a greater abundance of invertebrates but not a greater number of taxa (Ferreiro et al., 2011; Walker et al., 2013).

The taxa richness of S. biloba in Sánches Lake was similar to that reported by Poi de Neiff \& Neiff (2006) in studies conducted in shallow lakes connected to the Paraná river floodplain using similar methods. With regards to Egeria najas, we found a greater number of genera and families of invertebrates compared with those reported by other investigators (Ferreiro et al., 2011) for submerged aquatic plants in a stream of central Argentina, where amphipods and gastropods were the most abundant taxa.

The composition of invertebrate assemblages was different in the two types of habitat studied in Sánches Lake. Salvinia biloba has air fronds and supports semi-aquatic species such as Paulinia acuminata. This grasshopper feeds on the S. biloba air fronds (Vieira \& Adis, 2000 and 2002), suggesting a high specificity for its host plant.

S. biloba also had a higher number of genera of Coleoptera (Helochares spp., Enochrus spp., Derallus spp., Tropisternus spp., Paracymus spp., Berosus spp., Hydrochus spp., Desmopachria spp., Laccophilus spp., Liodessus spp. and $H y$ - 
drochanthus spp.) and Hemiptera (Belostoma spp., Pelocoris spp., Neoplea spp. and Ranatra sp.) than Egeria najas. The respiratory demands of some of these genera may be satisfied by a thin layer of air maintained along their body surface (plastron), which makes regular ascents to the water surface, and some others have a respiratory siphon to intake atmospheric oxygen. Gómez Lutz et al. (2015) found that the habitats and microhabitats (forming by different species of aquatic plants) directly influence the structure and the spatial and temporal variations of several species of Tropisternus.

Pseudopalaemon bouvieri is adapted to living in oligohaline waters of shallow lakes of Corrientes Province, and it is closely associated with E. najas. This freshwater prawn is known to have a relatively non-specific diet, feeding on algae, plant remains, Protozoa, Rotifera, Oligochaeta, Crustacea, Insecta, detritus, and other items (Carnevali et al., 2012).

The physical and chemical characteristics of the water varied in a narrow range during the sampling period, and the winter temperatures were sufficiently high for the development of aquatic plants and for allowing macroinvertebrate activity. However, the results of our study indicate a marked seasonal variability, both in terms of the total density, taxa richness, and the density of the populations of dominant taxa.

The largest number of invertebrate taxa was recorded during winter in the subtropical studied lake, a result that is in accord with another study (Fontanarrosa et al., 2013) carried out in the free floating plants of the Paraná river floodplain. The diversity and abundance of invertebrates are generally low in spring due to the early spring emergence of some species, but the total abundance cannot reflect these changes (Kratzer \& Batzer, 2007). However, in other shallow lakes of the study area, some populations of crustaceans, such as Hyalella curvispina (Galassi et al., 2006), reach their population peak in spring. Pseudopalaemon bouvieri increases their populations in spring-summer due to breeding occurring at the end of spring (Carnevali, 2012).

The habitat structuring of aquatic macrophytes is a key factor in the macroinvertebrate assemblages that should be included in comparative studies about vegetated wetlands with different habitat types. The strong temporal variation across seasons was a surprise in a subtropical climate, where the pronounced seasonality is absent.

\section{ACKNOWLEDGEMENTS}

This research was supported by the project "Analysis of ecological condition of peri-urban ponds (Corrientes, Argentina)" PI 2011Q001 SGCYT of the National University of Northeast (UNNE), Corrientes, Argentina. The authors thank the technical assistants of the Centro de Ecología Aplicada del Litoral (CECOAL) for field assistance and for water chemical analysis.

\section{REFERENCES}

ANGRISANO, E.B. 1992. El orden Trichoptera en la Argentina y países limítrofes. Physis, 50: 118-119.

BATZER, D.P. \& S.A. WISSINGER. 1996. Ecology of insect communities in non tidal wetlands. $A n$ nual Review of Entomology, 41: 75-100.

BINI, L.M., S.M. THOMAZ, K.J. MURPHY \& A.F.M. CAMARGO. 1999. Aquatic macrophyte distribution in relation to water and sediment conditions in the Itaipu Reservoir, Brazil. Hydrobiología, 415: 147-154.

CARNEVALI, R.P., P.A. COLLINS \& A.S.G. POI DE NEIFF. 2012. Trophic ecology of the freshwater prawn, Pseudopalaemon bouvieri (Decapoda: Palaemonidae) in Northeastern Argentina, with remarks on population structure. Revista de Biología Tropical, 60: 305-316.

CLARKE, K.R. 1993. Non-parametric multivariate analysis of changes in community structure. Australian Journal of Ecology, 18: 117-143.

COLWELL, K.R. \& J.A. CODDINGTON. 1994. Estimating terrestrial biodiversity through extrapolation. Philosophical transactions of the Royal Society of London Series.

CYR, H. \& J.A. DOWNING. 1988. Empirical relationships of phytomacrofaunal abundance to plant biomass and macrophyte bed characteristics. Canadian Journal of Fisheries and Aquatic Sciences, 45: 976-984. 
DIBBLE, E.D \& S.M. THOMAZ. 2009. Use of fractal dimension to assess habitat complexity and its influence on dominant invertebrates inhabiting tropical and temperate macrophytes. Journal of Freshwater Ecology, 24: 93-102.

DI RIENZO, J.A., F. CASANOVES, M.G. BALZARINI, L. GONZALEZ, M. TABLADA \& C.W. ROBLEDO. 2013. InfoStat. Grupo InfoStat, FCA, Universidad Nacional de Córdoba, Argentina. URL http://www.infostat.com.ar.

DOMÍNGUEZ, E. \& H.R. FERNÁNDEZ. 2009. Macroinvertebrados bentónicos sudamericanos. Sistemática y biología. Fundación Miguel Lillio. Tucumán, Argentina.

ESTEVES, F. (Coordinator). 2011. Fundamentos de limnología, tercera edición. Editora Interciencia Ltda.

FERREIRO, N., C. FEIJOÓ, A. GIORGI \& L. LEGGIERI. 2011. Effects of macrophyte heterogeneity and food availability on structural parameters of the macroinvertebrate community in a Pampean stream. Hydrobiología, 664: 199-211.

FONTANARROSA, M. S., G. N. CHAPARRO \& I. O'FARREL. 2013. Temporal and spatial patterns of macroinvertebrates associated with small and medium-sized free-floating plants. Wetlands, 33: 47-63.

GALASSI, M.E., M.C. FRANCESCHINI \& A. POI de NEIFF. 2006. Population estimates of Hyalella curvispina Shoemaker (Amphipoda) in aquatic vegetation of Northeastern Argentinian ponds. Acta Limnologica Brasiliensia, 18: 101-108.

GÓMEZ LUTZ, M.C., A.I. KEHR \& L.A. FERNÁNDEZ. 2015. Spatial distribution, temporal variation and specificity of microhabitat of Tropisternus species (Coleoptera: Hydrophilidae) in permanent ponds. Neotropical Entomology, 44: 256-263.

HAMMER, Ø., D.A.T. HARPER \& P.D. RYAN. 2001. PAST: Paleontological statistics software package for education and data analysis. Palaeontología electrónica. URL http://palaeo-electronica. org.

JACOBSEN, D., C. CRESSA, J. M. MATHOOKO \& D. DUDGEON. 2008. Macroinvertebrates: composition, life histories and production. In: Tropical streams ecology. D. Dudgeon (Ed.), Elsevier, USA.

KRATZER, E.B. \& D.P. BATZER. 2007. Spatial and temporal variation in aquatic macroinvertebrates in the Okefenokee swamp, Georgia, USA. Wetlands, 27: $127-140$.
LACHAVANNE, J.B. \& R. JUGE (eds.). 1997. Biodiversity in land-inland water ecotones. Man and the Biosphere Series. UNESCO and Parthenon Publ., París, Francia.

LIBONATTI, M.L., M.C. MICHAT \& P.L.M. TORRES. 2011. Key to the subfamilies, tribes and genera of adult Dytiscidae of Argentina (Coleoptera: Adephaga). Revista de la Sociedad Entomológica Argentina, 70: 317-336.

LOPRETTO, E.C. \& G. TELL. 1995. Ecosistemas de aguas continentales. Metodología para su estudio. Ediciones Sur, La Plata, Argentina.

MATSUDA, J.T., F.A. LANSAC-TÔHA, K. MARTENS, L.F. MACHADO VELHO, R.P. MORMUL \& J. HIGUTI. 2015. Association of body size and behaviour of freshwater ostracods (Crustacea, Ostracoda) with aquatic macrophytes. Aquatic Ecology, 49: 321-331.

MCABENDROTH, L., P.M. RAMSAY, A. FOGGO, S.D. RUNDLE \& D.T. BILTON. 2005. Does macrophyte fractal complexity drive invertebrate diversity, biomass and body size distributions? Oikos, 111: 279-290.

MEERHOFF, M., N. MAZZEO, B. MOSS \& L. RODRÍGUEZ-GALLEGO. 2003. The structuring role of free-floating versus submerged plants in a subtropical shallow lake. Aquatic Ecology, 37: 377-391.

MICHAT, M.C., M. ARCHANGELSKY \& A.O. BACHMANN. 2008. Generic keys for the identification of larval Dytiscidae from Argentina (Coleoptera: Adephaga). Revista de la Sociedad Entomológica Argentina, 67: 17-36.

MILLER, A., M.A. HANSON, J.O. CHURCH, B. PALIK, S. BOWE \& M.G. BUTLER. 2008. Invertebrate community variation in seasonal forest wetlands: implications for sampling and analyses. Wetlands, 28: 874-881.

MONÇÃO, F.S., A.M. DOS SANTOS \& L.M. BINI. 2012. Aquatic macrophyte traits and habitat utilization in the Upper Paraná River floodplain, Brazil. Aquatic Botany, 102: 50-55.

NEIFF, J.J. 1986. Aquatic plants of the Paraná system. Cap. 11A: 557-571. In: The Ecology of River Systems. Davies, B.R. \& K.F. Walker (Eds.) Dr. W. Junk Publishers. The Netherlands.

POI DE NEIFF, A. \& R. CARIGNAN. 1997. Macroinvertebrates on Eichhornia crassipes roots in two lakes of the Paraná River floodplain. Hydrobiología, 345: 185-196. 
POI DE NEIFF, A. \& J.J. NEIFF. 2006. Riqueza de especies y similaridad de los invertebrados que viven en plantas flotantes de la planicie de inundación del río Paraná. Interciencia, 31: 220-225.

POI, A. \& M.E. GALASSI. 2013. Humedales de la planicie aluvial del río Paraná entre Confluencia y Reconquista. In: Inventario de los humedales de Argentina, sistemas de paisajes de humedales del corredor fluvial Paraná-Paraguay. Benzaquén, L., D.E. Blanco, R.F. Bó, P. Kandus, G.F. Lingua, P. Minotti, R.D. Quintana, S. Sverlij \& L. Vidal (eds.): 161-168. Secretaría de Ambiente y Desarrollo Sustentable de la Nación. Proyecto Pesca y Humedales Fluviales. Buenos Aires, Argentina.

RAMÍREZ, A. 2010. Odonata. Revista de Biología Tropical, 58: 97-136.

RASBAND, W.S. 1997-2015. ImageJ 1.49 v. U.S. National Institutes of Health, Bethesda, Maryland, USA, http://imagej.nih.gov/ij/.

SUGIHARA, G. \& R.M. MAY. 1990. Applications of Fractals in Ecology. Trends in Ecology and Evolution, 5: 79-86.

TESSIER, C., A. CATTANEO, B. PINEL-ALLOUL, G. GALANTI \& G. MORABITO. 2004. Biomass, composition and size structure of invertebrate communities associated to different types of aquatic vegetation during summer in Lago di Candia (Italy). Journal of Limnology, 63: 190-198.

THOMAZ, S.M., E.D. DIBBLE, L.R. EVANGELISTA, J. HIGUTIY \& L.M. BINI. 2008. Influence of aquatic macrophyte habitat complexity on invertebrate abundance and richness in tropical lagoons. Freshwater Biology, 53: 358-367.

THORP, J.H. \& A.P. COVICH. 2001. Ecology and classification of North American Freshwater In- vertebrates. Second edition. Academic Press, New York, NY, USA.

TRIVINHO-STRIXINO, S. \& G. STRIXINO. 1995. Larvas de Chironomidae (Diptera) do estado de São Paulo: guia de identificação e diagnose dos gêneros. Universidade Federal de São Carlos. São Carlos, Brasil.

VIEIRA, M.F. \& J. ADIS. 2000. Aspectos da biología e etología de Paulinia acuminata (De Geer), 1773 (Orthoptera: Pauliniidae), um gafanhoto semiaquático, na amazônia central. Acta Amazonica, 30: 333-346.

VIEIRA, M.F. \& J. ADIS. 2002. Aceitabilidade alimentar de Paulinia acuminata (De Geer, 1773) (Orthoptera: Pauliniidae) na várzea da amazônia central. Acta Amazonica, 32: 333-338.

VIEIRA, L.C.G., L.M. BINI, L.F. M. VELHO \& G.R. MAZÃRO. 2007. Influence of spatial complexity on the density and diversity of periphytic rotifers, microcrustaceans and testate amoebae. Fundamental and Applied Limnology, 170: 77-85.

WALKER, P.D., S. WIJNHOVEN \& G. VAN DER VELDE. 2013. Macrophyte presence and growth form influence macroinvertebrate community structure. Aquatic Botany, 104: 80-87.

WARFE, D.M., L.A. BARMUTA \& S. WOTHERSPOON. 2008. Quantifying habitat structure: surface convolution and living space for species in complex environments. Oikos, 117: 1764-1773.

WILLBY, N.J., V.J. ABERNETHY \& B.O.L. DEMARS. 2000. Attribute-based classification of European hydrophytes and its relationship to habitat utilization. Freshwater Biology, 43: 43-74. 